\title{
Kekuatan Visual dalam Mendisiplinkan Khalayak di Masa Pandemi Covid-19
}

\author{
Sandi Jaya Saputra \\ Fakultas Ilmu Komunikasi, Universitas Padjadjaran \\ sandi.jaya.saputra@unpad.ac.id
}

\begin{abstract}
In this article, the author dissected two photos published by two mass media by describing the situation of the Covid-19 pandemic in Indonesia. The two photos serve as an entry point to see the position of Indonesia's visual culture in facing the Covid-19 pandemic, visual culture here is seen from the mass media approach using photography as a representation of Indonesia. Photography does not only prioritize aspects of beauty, but is able to describe complexity, problems and at the same time open up space for discussion and how to understand the cultural power of Indonesia. This article is not in the aim of having the pretense to simplify or even bypass the leap in Indonesian visual culture, but how to place the full awareness of the audience in the face of a "disaster". At this point, the writer tries to dismantle the mythical meaning in the two photos that will be uncovered. The author's aim is to show the complexity of cultural problems, particularly related to visual culture, by borrowing two photos taken from the mass media. The two photos were selected on the basis of being able to represent the reality of Indonesia in dealing with the Covid-19 pandemic. This article uses Barthesian semiology. The aim is to explore how a visual, has sensory power with its power that is capable of determining behavior. In this article, the author describes the relation between photography practice and the discourse of the Covid-19 pandemic in Indonesia, which can be productive as well as counterproductive. This research wants to show that, in this case visual photography, is one of the mediums in the form of signs which possess ideology, as a contribution of thought for the government to be literate in maximizing the medium, in this case photography.
\end{abstract}

Keywords: Covid-19; photography; pandemic; semiotic; visual

\begin{abstract}
Abstrak
Dalam artikel ini, penulis membedah dua foto yang dimuat oleh dua media massa dengan menggambarkan situasi pandemi Covid-19 di Indonesia. Dua foto tersebut berperan sebagai pintu masuk untuk melihat posisi budaya visual Indonesia dalam menghadapi pandemi Covid-19, budaya visual disini dilihat dari pendekatan media massa menggunakan fotografi sebagai representasi Indonesia. Fotografi bukan hanya mengedepankan aspek indah, melainkan mampu menggambarkan kompleksitas, problematika sekaligus membuka ruang diskusi dan bagaimana memahami daya kebudayaan Indonesia. Artikel ini tidak dalam tujuan memiliki pretensi untuk menyederhanakan bahkan memotong lompatan budaya visual Indonesia, namun bagaimana mendudukkan kesadaran penuh yang dimiliki khalayak dalam menghadapi sebuah "bencana". Pada titik ini, penulis berusaha untuk membongkar makna mitos pada dua foto yang akan di bongkar. Tujuan penulis adalah untuk memperlihatkan kompleksitas dari permasalahan kultural, khususnya yang bersangkutpaut dalam budaya visual, dengan meminjam dua foto yang diambil dari media massa. Dua foto tersebut dipilih atas dasar mampu menghadirkan ulang realitas Indonesia dalam menghadapi pandemi Covid-19. Artikel ini menggunakan semiologi Barthesian. Tujuannya adalah untuk mengupas bagaimana sebuah visual memiliki daya gempur indrawi dengan kekuatannya yang mampu menentukan perilaku khalayak. Dalam artikel ini, penulis memaparkan relasi praktik fotografi dengan wacana pandemi Covid-19 di Indonesia yang bersifat produktif atau bisa jadi kontraproduktif. Penelitian ini ingin menunjukkan bahwa visual, dalam hal ini fotografi merupakan salah satu medium dalam bentuk tanda
\end{abstract}

Korespondensi: Sandi Jaya Saputra, S.I.Kom.,M.Sn. Fakultas Ilmu Komunikasi Universitas Padjadjaran, Jl. Raya Bandung Sumedang KM.21, Kec. Jatinangor, Kabupaten Sumedang, Jawa Barat, 45363, Email: sandi.jaya.saputra@unpad.ac.id Menyerahkan: Juni 2020, Diterima: November 2020, Terbit: Januari 2021

ISSN: 2549-0559 (cetak), ISSN: 2549-1946 (online), Website: http://jurnal.unpad.ac.id/kajian-jurnalisme 
yang di dalamnya memiliki ideologi, sebagai sumbangsih pemikiran untuk pemerintah agar melek dalam memaksimalkan medium, dalam hal ini fotografi.

Kata kunci: Covid-19; fotografi; pandemi; semiotik; visual

\section{PENDAHULUAN}

Fotografi menjadi salah satu bagian dari bentuk visual dua dimensi yang cukup populer untuk saat ini, "seakan semua menjadi fotografer". Agan Harahap sebagai salah satu seniman fotografi kontemporer terkemuka di Indonesia yang menggunakan medium fotografi, membenarkan fenomena tersebut. Fotografi atau visual menjadi salah satu "kekuatan" baru dalam memengaruhi khalayak. Salah satu contohnya adalah karya Agan Harahap yang viral dengan menggunakan teknik olah digital ikan louhan, dimana Agan memanipulasi ikan louhan tersebut seakan memiliki "tanda lahir" logo Partai Komunis Indonesia (PKI). Hal tersebut sempat heboh di media massa dan media sosial, dengan dorongan media massa dan media sosial yang serba "visual". Fotografi memiliki peran penting dalam keseharian khalayak, apalagi pada masa pandemi Covid-19. Bermedia sosial dan "berfotografi" menjadi salah satu aktivitas keseharian pada masa pandemi, dilansir katadata.co meningkat 40\%, terutama pengguna Whatsapp dan Instagram (Burhan, F.A., 2010).

Dalam tulisan ini, penulis menawarkan alur dalam meretas visual dengan pemahaman yang lebih spesifik. Pertama, dilihat dari budaya visual. Kedua, bagaimana sebuah visual mampu "mendisiplinkan" khalayak dan ketiga, bagaimana visual tersebut memiliki penekanan kaidah estetik dan praktik kreatif. Tiga gambaran foto tersebut yang coba penulis retas, dalam kaitannya bagaimana sebuah visual memiliki kekuatan dalam mendisplinkan khalayak. Terlebih pada masa pandemi Covid-19 kali ini. Tulisan ini terbatas memandang hubungan tiga hal tersebut dalam cara pandang visual untuk melihat lebih luas, dalam hal ini kondisi "lebih luas" bagaimana melihat Indonesia dalam menangani pandemi dilihat dari pendekatan visual, dalam hal ini karya fotografi.

Fotografi dan media massa adalah kata kunci yang menjadi pintu masuk dalam penelitian ini, karena foto yang penulis analisis adalah foto yang tampil pada media massa. Secara spesifik, media digital atau dot com. Media berbasis digital hari ini jangkauannya sangat baik, apalagi pada masa pandemi. Sebagai salah satu cara mengurangi kontak dengan banyak pihak, bukan berarti media "konvensional" tidak ada yang "layak", karena penulis mengambil fenomena pada masa pandemi. Maka media digital lebih relevan, menurut penulis. Media digital hadir sebagai bentuk mediamorfose dari media konvensional, lalu sebagai bentuk terus berkembang dan beradaptasi (Fidler, 2010).

Ekosistem media massa di Indonesia memang mengalami banyak perubahan sejak kehadiran internet (Haq, A.D \& Fadilah, 2018). Sama halnya juga dengan tradisi melihat, apalagi dimasa pandemi. Perhatian khalayak tertuju pada media digital, dimana pada era digital, proses penyebaran informasi oleh media konvensional tidak lagi terpaku pada saluran utama, tetapi sudah memanfaatkan berbagai medium (Insani, Hidayat \& Zulfan, 2019). Berbagai perubahan tersebut, membawa perubahan pada satu kondisi khalayak pada konteks budaya visual.

Hal yang perlu disadari adalah bahwa visual memiliki kekuatan dan kompleksitas tersendiri, dalam membentuk cara pandang dan tampilan dalam tradisi kebudayan. Bagaimana sebuah visual, dalam hal ini fotografi mampu mendisiplinkan khalayak luas dan seberapa efektif fotografi menjadi medium untuk mendisplinkan khalayak dalam kaitannya dengan pandemi Covid-19.Selain bagaimana cara meretas atau membedah sebuah visual, dalam konteks ini adalah fotografi, penulis merasa perlu untuk mendudukkan apa itu visual dan kekuatan "power". Dalam hal ini penulis membagi dua argumentasi, yaitu pertama apa itu visual dan 
kekuatan atau "power". Visual adalah pancaran spektrum warna yang diserap oleh indrawi. Menurut Barthes (2010), apa yang kita sebut visual adalah karena spektrum tersebut kita kenal sebagai teks. Maka kita bisa memotret meja karena kita mengenal diksi meja, itulah visual. Selain proses indrawi, visual ditentukan oleh cara melihat visual atau gambar tersebut, atau dengan kata lain, pengetahuan yang melihat visual menentukan cara membaca visual tersebut (Barger, 2008).

Kedua adalah apa itu kekuatan. Kekuatan adalah dorongan eksternal yang mampu mengontrol khalayak (Hemingway, 2006). Sebagi contoh, artikel ini mungkin tidak akan terbit, dengan berbagai pertimbangan karena ada "kekuatan" yang mengontrol. Itu sebagai contoh bagaimana kontrol atas nama "kekuatan". Apa yang penulis tawarkan adalah bagaimana kita melihat, menilai dan menelaah seberapa kuat visual mampu memengaruhi khalayak, yang selanjutnya mungkin mampu mendisiplinkan khalayak dalam hubungan sebagai pesan pemerintah pada masa pandemi Covid-19.

Sebagai "pegangan" dalam menelaah visual, penulis menggunakan dua fondasi paradigma dalam mendefinisikan apa itu kekuatan visual. Penulis menggunakan Marxisme dan Michel Foucault. Dua pemikir besar ini mendefnisikan kekuatan dengan cara berbeda, tetapi memiliki penguatan yang cukup signifikan sebagai pegangan penulisan. Marx melihat kekuatan "power" sebagai sebuah kekuatan yang mampu mengontrol. Dengan kata lain Marx melihat bahwa visual memiliki kesadaran tertentu dalam membentuk identitas (Hemingway, 2006). Sedangkan Foucault (1970) dengan teorinya tentang panopticon. Kangsong (2020) menuliskan judul editorialnya "Panopticon Covid-19" menggambarkan situasi hari ini, dengan pandemi Covid-19 khususnya di Indonesia bahwa kekuatan "power" yang kasat mata, bekerja dalam alam sadar khalayak. Khalayak terdisiplinkan karena susuatu yang kita yakini, tetapi mungkin tidak tampak. Foucault menggabarkan situasi hari ini dengan mengambil ide panoptisisme dari model arsitektur penjara rancangan filsuf Inggris, Jeremy Benthan yang menulisnya dengan istilah panopticon.

Pemahaman terhadap situasi tertentu dalam memaknai antara visual dan power, kemudian diharapkan mampu menerjemahkan menjadi bentuk yang lebih konkret. Tujuannya untuk menghasilkan potensi visual tersebut dengan kaitan pandemi Covid-19, karena visual dalam kaitan ini adalah fotografi dipercaya tidak hanya menjadi sebuah sajian pemanis halaman media massa, tetapi juga mampu menguliti lapis demi lapis kesadaran dan kehidupan kultural di masa pandemi.

Selain menggunakan dua paradigma, kekuatan visual dalam konteks pandemi Covid-19 harus dilihat dari cara pandang budaya visual Indonesia. Budaya visual, apabila didefinisikan akan lebih luas ketimbang seni rupa yang hanya fokus pada pendekatan estetik, bentuk dan lainnya. Budaya visual tidak membatasi objek kajiannya, budaya visual adalah produk masyarakat dan zamannya dalam tradisi visual di Indonesia (Hariyanto, 2017). Pada konteks ini, yakni pandemi Covid-19 sangat jarang kita menemukan begitu masif khalayak menggunakan masker, atau dokter menggunakan alat pelindung diri (APD). Hal ini bisa dipandang sebagai sebagai "new normal".

Melihat Indonesia sebagai negara yang cukup rawan bencana alam, penulis baru melihat aktivitas khalayak menggunakan masker dalam sebuah foto jurnalistik pada saat Gunung Merapi di Yogyakarta. Saat itu ada kesadaran dari masyarakat menggunakan masker, tetapi itu pun tidak masif. Gambaran visualnya ditangkap dengan baik oleh Jufri (2017) yang meraih juara kedua photo story kategori people in the news dalam worldpressphoto, November 2010. Dalam foto tersebut, digambarkan bahwa masyarakat Jawa Tengah menggunakan masker karena debu yang dihembuskan gunung berapi. 
Pendisiplinan khalayak menggunakan masker dicoba dibudayakan pada saat pandemi Covid-19 kali ini, bisa dilihat bagaimana Presiden Indonesia, Joko Widodo dalam beberapa kesempatan selalu menggunakan masker. Dalam hal ini penulis menyoroti visual saat Jokowi melantik Wakil Gubenur Jakarta, Ahmad Riza Patria. Bagi penulis, foto ini cukup penting, karena menggambarkan sesuatu yang mendesak dalam acara seremonial yang dilakukan di tengah pandemi Covid-19. Foto kedua adalah foto dimana anggota Dewan Perwakilan Rakyat menggunakan APD pada saat sesi pemotretan sebelum berangkat untuk memberi bantuan. Foto ini bagi penulis cukup penting untuk menjelaskan pengetahuan dan kesejalanan program pemerintah mengenai pandemi Covid-19. Bagi penulis ini cukup penting untuk menggambarkan situasi terkini saat pandemi Covid-19.

Mengutip pandangan Louis Althusser mengenai coupure, coupure digunakan oleh penulis sebagai pegangan dalam melihat budaya visual yang "meloncat jauh".Althusser menggunakan istilah tersebut dalam mendefinisikan epistemological break sebagai lompatan ide. Ada perubahan radikal dan problematik dalam pola kontruksi ideologi antara tradisional dan modern. Bagi Althusser, konsep coupure atau epistemological break adalah proses untuk memahami dealektikal materialisme dan hubungannya dengan ideological philosophy Karl Marx (Slater \& Althusser, 1980).

Merujuk pada fakta tersebut, maka coupure dalam budaya visual di Indonesia dalam menghadapi pandemi adalah kebiasaan mengahadapi bencana, atau lebih spesifiknya menggunakan masker atau protokol kesehatan. Kondisi ini yang tidak diciptakan secara ideal meskipun Indonesia sebagai negara yang cukup rawan bencana alam. Hal yang paling konkret dalam lompatan budaya visual Indonesia adalah kebiasaan menggunakan masker.

Dengan dorongan teknologi visual, pada masa pandemi, hiburan khalayak adalah visual. Menonton televisi, menikmati media massa dengan perangkat teknologi (handphone, laptop dan sebagainya) adalah peluang yang perlu dilakukan oleh pemerintah untuk mengkonstruksi khalayak, karena teknologi untuk menikmati visual mampu mengubah pemahaman dan pengalaman kita terhadap makna citra atau image dalam keseharian. Kebiasan menggunakan masker dan protokol kesehatan bisa dianggap sebagai "kenormalan" baru dalam keseharian.

Dengan medium visual, dalam hal ini fotografi, memungkinkan subjeknya menghadirkan ulang dirinya dengan berbagi cara, tujuannya untuk membentuk ikatan sosial secara visual dan nyata. Dengan visual, dalam hal ini fotografi, kita dapat saling bertukar informasi seputar keseharian, ekonomi, politik, hukum dan sebagainya. Informasi tersebut mampu dengan mudah menyebar ke khalayak yang menggunakan berbagai platform. Melihat bagaimana visual sangat penting dan menjadi salah satu medium dalam mengkonstruksi khalayak, pada konteks tersebut fotografi memiliki kekuatan. Maka pertanyaannya adalah, apakah dari dua visual yang penulis bedah cukup mampu memanfaatkan medium fotografi sebagai cara untuk mendisiplinkan khalayak dalam menghadapai kenormalan baru.

Berdasarkan penelitian awal penulis, diambil dua foto tersebut yang cukupmenggambarkan keadaan pandemi Covid-19. Foto tersebut memberikan gambaran bagaimana sebuah kekuatan visual mampu mendisplinkan secara produktif atau bisa jadi kontraproduktif. Mengingat dimana visual memberikan efek yang cukup kuat dalam membentuk khalayak dan bagaimana fotografi sebagai medium mampu di representasikan secara optimal oleh pemerintah.

Dua foto yang akan dibedah adalah gambaran sikap di bawah alam bawah pemerintah dalam menangani pandemi Covid-19. Merujuk pada Andre Bazin, waktu telah berhasil dibalsamkan, "embalms time, rescuing it simply from its proper corruption" atau Bazil memaparkan jika proses ini sebagai mummification atau dipahami sebagai reproduksi visual menggunakan reproduksi mekanikal. Fotografi bisa disebut sebagai medium yang menggunakan mekanikal produksi, 
124 | Kajian Jurnalisme

Volume 04 Nomor 02 Tahun 2021

DOI: $10.24198 / \mathrm{jkj} . \mathrm{v} 4 \mathrm{i} 2.27811$

seakan tanpa campur tangan fotografer. Apabila dibanding dengan seni lukis (Bazin \& Gray, 2009). Sejalan dengan budaya visual, fotografi sebagai medium cukup menggambarkan ulang realitas. Proses menggambarkan ulang atau representasi ini yang dipersoalkan oleh penulis, representasi sendiri merujuk kepada proses realitas yang disampaikan dalam komunikasi, via kata-kata, bunyi, citra, atau kombinasinya (Fiske, 2004).

Walter Benjamin melihat hubungan antara lompatan budaya visual yang merupakan coupre harus disadari sebagai lompatan, lompatan dimana kita melihat posisi Indonesia dalam menghadapi pandemi Covid-19 sebagai kajian visual. Fotografi sebagai produk mekanik digital harus bisa dilihat sebagai apa yang khalayak lihat, alami dan bagaimana membenamkan khalayak bukan hanya sebagai citra, melainkan representasi dari citra atau biasa disebut sebagai the image of time. Barthes (2010) memaparkan dengan baik mengenai fenomena fotografi yang menghasilkan dua "efek" yaitu studium dan punctum. Secara sederhana, dua hal tersebut memperlihatkan efek yang melekat pada proses khalayak mengenali, memahami dan "terusuk" oleh karya fotografi.

Maka dari itu, untuk menentukan representasi diri dua foto yang akan dibedah, peneliti menggunakan metodologi kritis semiotik Roland Barthes. Karena dalam hal ini, kehadiran foto pada sebuah berita atau iklan tidak lebih dari sekedar indeks atau bahan untuk menghilangkan suasana membosankan. Bisa dimaknai bahwa foto mempunyai nilai denotatif atau estetis dalam suatu layout. Foto sudah dipandang sebagai realitas itu sendiri sehingga orang tidak perlu mempersoalkannya lagi. Kebiasaan tidak mempersoalkan inilah yang justru dipersoalkan oleh Barthes. Barthes berpendapat bahwa foto dapat membantu kita untuk mengembangkan subjektivitas dengan "membacanya" (Sunardi, 2004).

Semiotik model Barthes menekankan kepada gagasan mengenai tatanan pertandaan (order of signification) yang terdiri dari denotasi, konotasi dan mitos. Maka penulis menilaitepat apabila proses representasi dibedah menggunakan pendekatan semiotik. Artikel ini akan menjawab dua pertanyaan utama. Apakah dari dua visual yang penulis bedah, pemerintah sudah cukup mampu memanfaatkan medium fotografi sebagai cara untuk mendisiplinkan khalayak dalam menghadapai kenormalan baru. Kedua, bagaimana melihat representasi pemerintah dalam menghadapi pandemi Covid-19.

\section{METODE}

Melihat pada subjek penelitian, penulis melihat bagaimana realitas dari subjek tersebut dipindahkan pada medium representasi, yaitu fotografi. Maka penggunaan metode Roland Barthes menjadi lebih tepat sebagai rujukan apabila melihat sebuah kajian tentang representasi yang representasinya merujuk kepada proses realitas, via kata-kata, bunyi, citra, atau kombinasinya (Fiske, 2004). Representasi juga disebut sebagai cara bagaimana media menginterpretasikan dunia, atau realitas eksternal lainnya (Rayner, P et al., 2001). Trifonas (2003) menyebutkan representasi sebagai wahana yang dengannya dua hal yang tidak berkaitan dipersatukan untuk mengacu pada sebuah konsep. Korespondensi menjadi dasar dalam pandangan representasi dengan sesuatu yang direpresentasikan.

Bagaimana representasi membedah dua foto yang penulis analisis pada kekuatan visual dalam mendisplinkan khalayak dimasa pendemi covid-19 adalah seperti halnya yang diungkapkan Barthes. Barthes berpendapat bahwa foto dapat membantu untuk mengembangkan subjektivitas manusia dengan "membacanya" (Sunardi, 2004).

Wacana kekuatan visual dalam karya fotografi adalah representasi politik pada masa pandemi Covid-19. Wacana merupakan satu hal yang penting dalam semiotik Barthes yang termasuk dalam post-srukturalisme. Barthes bekerja dalam tiga tahap, yakni denotasi, konotasi 
dan mitos. Denotasi adalah tatanan yang menggambarkan relasi antara penanda dan petanda di dalam tanda dan antara tanda dalam realitas ekternal. Secara mudah, denotasi adalah apa yang anda lihat pertama kali. Sedang konotasi menggambarkan interaksi yang berlangsung ketika tanda bertemu dengan perasaan atau emosi penggunanya dengan nilai-nilai sosio-kulturalnya, atas dasar makna denotasi. Sedangkan mitos adalah cerita yang digunakan suatu kebudayaan untuk menjelaskan atau memahami beberapa aspek dari realitas atau alam. Untuk Barthes sendiri, mitos merupakan cara berpikir dari suatu kebudayaan tentang sesuatu hal, cara untuk mengonseptualisasikan atau memahami sesuatu (Barthes, 2010).

\section{HASIL DAN PEMBAHASAN}

Merujukpada argumentasi Thomas Weskidalam sebuahwawancara dimedia Conscientious (Colberg, 2013), bagaimana sebuah kesadaran adalah cara memilih dan membekukan citraan akan dunia realitas. Dihadirkan kembali dengan kesadaran bahwa pemotret dan konseptor visual memiliki gagasan artistik sebagai konsep visual yang akan dihadirkan kembali dari bentukan realitis.

Weski memiliki pandangan bahwa karya foto atau visual dalam koridor seni kontemporer, di mana dalam karya - karya foto dan visual memiliki kecenderungan pada permasalahan makna 'teks' dan konsep, daripada permasalahan foto itu sendiri (Colberg, 2013). Hal yang menariknya adalah fotografi dalam era kontemporer sudah tidak lagi membicarakan representasi, tetapi lebih jauh lagi, yaitu fotografi atau visual mempermasalahkan persoalan. Seperti halnya sebuah karya seni pada umumnya, yakni bagaimana persoalan realitas dijadikan argumentasi dalam berkarya yang berdasarkan hasil riset fotografer, konseptor visual dan sebagainya.

Dengan argumen tersebut, pada dasarnya penulis menawarkan dan mengajak para pengamatnya untuk fokus pada subjek - subjek yang berbeda dengan sebuah cara pandang baru yang lebih terbuka (Demos, 2006). Melihat hal tersebut, penulis melihat bagaimana problematika repersentasi ini hadir dalam pandemi Covid-19, alih - alih ingin mendisiplinkan bisa jadi menjadi humor belaka. Disadari atau tanpa disadari adalah kekuatan visual, dalam hal ini fotografi, menjadikan bagaimana penulis melihat kekutan visual sebagai representasi dari identitas yang terbentuk oleh budaya visual, dalam hal ini terkait dua visual atau fotografi.

Dalam fotografi dan hubungannya dengan pandemi, fotografi bertujuan untuk menunjukkan apa yang tidak bisa dilihat oleh mikroskopi (Smith, 2013). Dengan fotografi atau visual, kita bisa merasakan berfungsinya semua indrawi untuk memantik empati dan kedisiplinan alam bawah sadar. Pada dasarnya, kesadaran ideologi terkait kekuatan visual akan berfungsi jika ada tanda itu sendiri (Voloshinov, 1986). Demikian pula fotografi pada akhir abad ke-19 bertujuan untuk menangkap wabah sebagai penyakit efek dari sebuat virus (Foucault, 2014).

Fotografi dalam prosedur epidemiologis, bukan hanya apa yang terjadi, tetapi apa yang telah dan terlihat juga, maka fotografi digunakan sebagai petanda dalam sebuah peristiwa zaman (Barthes, 2010). Maka menelaah apa yang tampak dan apa yang menjadikan foto tersebut ideologi adalah kemampuan dalam mengorkestra tanda yang menjadikannya sebuah pesan bagi yang dituju, dalam hal ini khalayak yang merasakan pandemi Covid-19 ini, karena visual salah satunya mampu mendorong emosi. E.H. Gombrich menyebutkan bahwa dibutuhkan kemampuan pengetahuan untuk memahami konteks, karena dalam visual harus menghubungkan berbagai tanda menjadi satu nilai (Wolff, 2015).

Untuk membedah karya ini, penulis menggunakan paradigma budaya visual dan "power" ala Marxisme dan Foucault. Dua hal tersebut menjadi pegangan dalam meretas kekuatan visual dimasa pandemi Covid-19. Tujuannya untuk menghadirkan penerjemahan dari kebutuhan 
indrawi yang berakar pada kebutuhan biologis manusia, dengan beralasan pada kebutuhan biologis manusia. Mandoki (2012) memaparkan bahwa manusia pada dasarnya memiliki sensasi - sensasi yang kuat untuk mempertajam selera akan realitas.

Selain dua paradigma di atas, penelitian ini akan dipandu menggunakan kajian metodologi kritis, yakni semiotika model Barthes. Setiap image akan dibedah menggunakan tiga tahap, yakni denotasi, konotasi dan mitos. Denotasi melihat permukaan dalam visual atau apa yang tampak dalam visual. Sedangkan konotasi adalah petanda kedua yang menjelaskan hal apa yang ada dalam alam bawah sadar kita, sebagai pembaca visual atau dalam konteks ini hasil jepretan fotografi. Terakhir adalah mitos, dimana mitos dipandang sebagai cara untuk mendudukan kembali kedudukan denotasi, tetapi bedanya mitos ini diambil dari analisis kebudayan, dimana "mitos" tersebut diproduksi sebagai kebudayaan.

Dengan meminjam Barthes, Barthes mampu menguliti bentuk visual foto seremonial pelantikan Wakil Gubenur DKI Jakarta, Ahmad Riza Patria dan foto Tim \#satgaslawancovid19 DPR RI sebagai kekuatan visual yang produktif atau sebaliknya kontraproduktif dimasa pandemi Covid-19 melanda Indonesia. Dari dua foto tersebut, kita bisa melihat cara berfikirnya pemerintah menghadapi pandemi Covid-19.

\section{Pelantikan Wakil Gubernur Jakarta priode 2020}

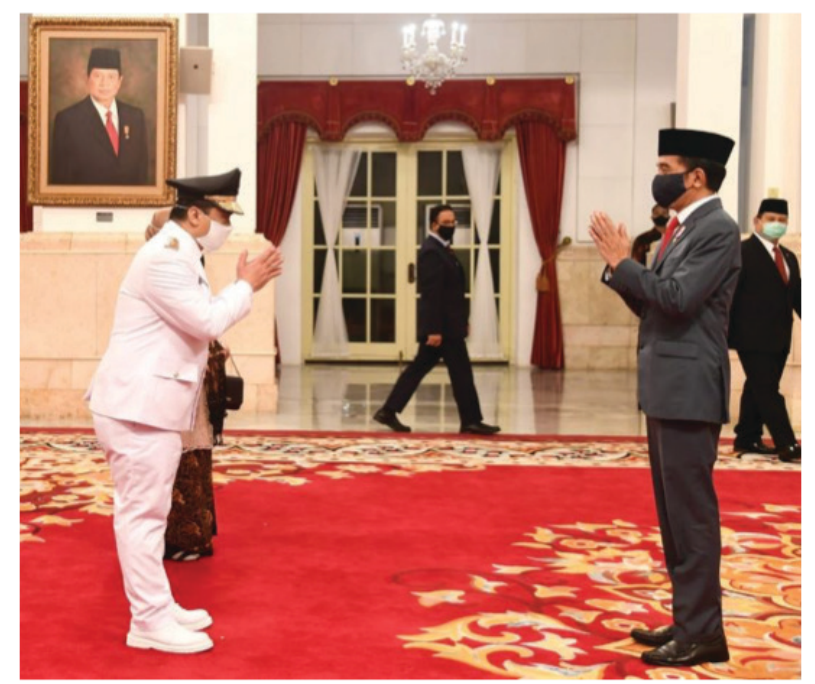

Sumber: Fathurrohman (2020)

Seperti yang dibahas di pendahuluan, masker menjadi sesuatu yang tidak lazim dalam budaya visual di Indonesia atau sesuatu yang tidak familiar dalam keseharian khalayak Indonesia. Meskipun Indonesia adalah salah satu negara yang rawan bencana, masker bukan sebuah kebiasaan keseharian bagi khalayak di Indonesia secara luas. Selain masker, ornamen yang tampak yang cukup mencolok, selain atribut resmi seremonial pelantikan pejabat negara, adalah gestur berjabat tangan, pada kesempatan ini diganti menjadi "salam hormat", yang biasanya dilakukan jabat tangan. Bukan tanpa alasan, hal ini terjadi pada kegiatan pelantikan Wakil Gubenur DKI Jakarta, Ahmad Riza Patria dilakukan di tengah-tengah pandemi Covid-19. Masker dan gestur bersalaman menjadi landasan ketertarikan penulis untuk membedah foto ini.

Secara konotatif, masker dan cara bersalaman seperti ini menyiratkan adanya sesuatu yang berbahaya karena di luar kebiasan saat seremoni pelantikan. Masker yang biasanya diperuntukkan bagi tenaga medis, di masa pandemi Covid-19 ini digunakan oleh para pejabat negara. Meskipun masker yang digunakan berbeda dengan tenaga medis, yakni masker kain. 
Pada pelantikan Wakil Gubenur DKI Jakarta ini momennya cukup "sakral" yakni posisi Wagub DKI dengan Presiden Joko Widodo, momen ini biasanya kalau masuk ke rumah keluarga Indonesia, apalagi pejabat publik dalam tradisi ruang display dokumentasi foto akan dipajang di ruang tamu atau ruang keluarga. Bisa dibayangkan hal ini menjadi sesuatu yang istimewa atau pun menjadi kenangan yang tidak dilupakan karena dilakukan di masa pandemi Covid-19. Bagi yang melihat foto tersebut, akan merelasikan ingatannya pada momen atau langsung menghubungkan pada suatu yang sangat penting terjadi pada tahun 2020.

Dalam perspektif fotografer, seperti yang dilansir bjp-online.com, fotografer dan juga pembuat film Francesca Tosareli, memaparkan pengalaman sangat berharga di saat meliput kejadian pada masa pandemi Covid-19 di Itali. Melalui visual, masyarakat Itali menjadi lebih patuh pada instruksi pemerintah (Abel, 2020). Setidaknya ada kepuasan publik karena fotografi mampu mengartikulasikan objek-objek agar terjadinya pengungkapan keseluruhan psikis dalam indera manusia sebagai kesadaran optik (Benjamin, 1972). Khalayak bisa memahami bahwa Covid-19 benar - benar berbahaya. Hal serupa yang terjadi di Indonesia, kejadian dalam foto pelantikan Wagub DKI, bisa ditafsirkan seakan "menuntut" khalayak menggunakan masker, karena dilakukan dalam momentum yang tidak biasa dan juga mengubah tradisi bersalaman, masker menjadi seakan "gaya hidup" baru. Hal ini menandakan ada yang "mendesak" berbahaya, genting dan perlu dilakukan dalam segala momentum yang berkaitan dengan seremoni, kesehatan dan publik.

Secara semiologi, foto ini bagi penulis cukup "kuat" dalam memberikan pesan akan sesuatu yang sedang berbahaya, karena cukup menggambarkan sesatu yang "tidak biasa". Secara indrawi, "tidak biasa" dimaknai menjadi kepahaman akan kepatutan dalam tatanan keseharian. Hal ini cukup mengganggu khalayak karena dengan foto tersebut mengirimkan pesan mengenai dorongan stimulasi kepatuhan pada khalayak, karena dilakukan pada hal-hal yang tidak biasa. Seakan memberikan sinyal bahwa situasi pandemi Covid-19 sedang berbahaya dan masuk pada wilayah yang sangat formal dan seremonial, yang sebenarnya bisa dilakukan atau tidak dilakukan, kerena nilai keabsahan ada dalam sebuah perangkat keputusan administrasi, bukan pada seremonial pelantikan. Bagaimanapun, yang disahkan dalam pelantikan adalah lembaran dokumen administratif.

Seremoni, kesehatan dan publik menjadi pesan dalam foto pelantikan Wakil Gubenur DKI Jakarta priode 2020. Hal-hal yang seremonial dalam tradisi administratif adalah hal yang keseharian, coba kita komparasi. Meskipun tidak dalam jangka waktu yang terdekat, tetapi ini sebagai gambaran bagaimana pengelolaan bencana yang dimiliki pemerintah kurang tanggap.Dilansir detik.com, pasien yang pertama kali teridentifikai Covid-19 lalu dinyatakan sembuh. Menteri Kesehatan, Terawan Agus Purtanto langsung membuat acara seremoni untuk kesembuhan pasien positif Covid-19 kasus 1, 2 dan 3. Dengan memberikan buah tangan, yaitu jamu dari Presiden. Ini adalah hal yang remeh temeh dan harus ada dana dalam menyelenggarkan seremoni tersebut. Padahal kalau merujuk pada 6 Mei 2010, selang satu bulan yang positif Covid-19 berjumlah 12.438 .

Penulis melihat dari dua momentum tersebut mampu menghadirkan banyak kemungkinan. Pertama seremoni kesembuhan pasien 1, 2 dan 3 Covid-19 dan pelantikan Wakil Gubenur DKI Jakarta priode 2020 memiliki hal yang kontradiktif. Pada acara seremonial sembuhnya pasien covid-19 tersebut, semua pejabat yang hadir tidak menggunakan masker dan tidak menjaga jarak atau physical distancing. Sedangkan pada acara pelantikan Wakil Gubenur DKI Jakarta priode 2020, semua menggunakan masker, kecuali "Susilo Bambang Yudhoyono", tetapi masih jaga jarak. Hal ini menyiratkan, meskipun foto pelantikan cukup "kuat" secara visual memberikan pesan kedisiplinan menggunakan masker dan jaga jarak, tetapi di lain waktu 
128 | Kajian Jurnalisme

Volume 04 Nomor 02 Tahun 2021

DOI: $10.24198 / \mathrm{jkj} . \mathrm{v} 4 \mathrm{i} 2.27811$

protokol Covid-19 diabaikan.

Visualisasi dengan fotografi memiliki "efek" yang signifikan. Fotografi juga kehilangan aura dan keaslian (authenticity), hal ini mengutip dari esa fenomenal Benjamin "the Work of Art" bahwa fotografi memiliki masalah kultural dan seni visual khusunya fotografi (Benjamin, 2008).

Hubungannya dengan aura dan keaslian (authenticity), Benjamin menjelaskan tentang cara kerja reproduksi teknologi yang bersifat tradisional, kultus dan ritualistik "the reproduction to meet the beholder or listener in his own particular situation, it reactivates the object reproduced." Pola tersebut kalau tidak dipahami lebih menyeluruh, maka akan kehilangan konteksnya (Benjamin, 2008).

Maka dengan itu, hubungan antara pandemi Covid-19 dengan budaya visual, dan reproduksi teknologi adalah bagaimana pemerintah mampu membawa pada satu situasi dimana sebuah produksi media dengan mengedepankan teknologi bisa dibuat untuk memaksimalkan kebijakan pemerintah. Oleh karena itu, fotografi sebagai produk visual, membawa pada produksi media teknologi. Fotografi melahirkan film, sedangkan film melahirkan pula teknologi televisi. Saat ini komputer dan media digital menjadi "oligarki" media baru yang memiliki efek luar biasa bagi perubahan kebudayaan keseharian khususnya dalam ruang lingkup visual. Mengingat karena hal ini bisa dipakai sebagai cara pemerintah mereproduksi dan selanjutnya menjadi representasi dari sebuah kebijakan yang diambil pemerintah. Maka apabila bisa dipahami oleh pemerintah, fotografi mampu memberikan efek luar biasa bagi keseharian, khususnya keseharian dalam lingkup pandemi Covid-19 agar memberikan kebudayaan baru dalam mengahadapi protokol kesehatan.

\section{Tim \#satgaslawancovid19 DPR RI}

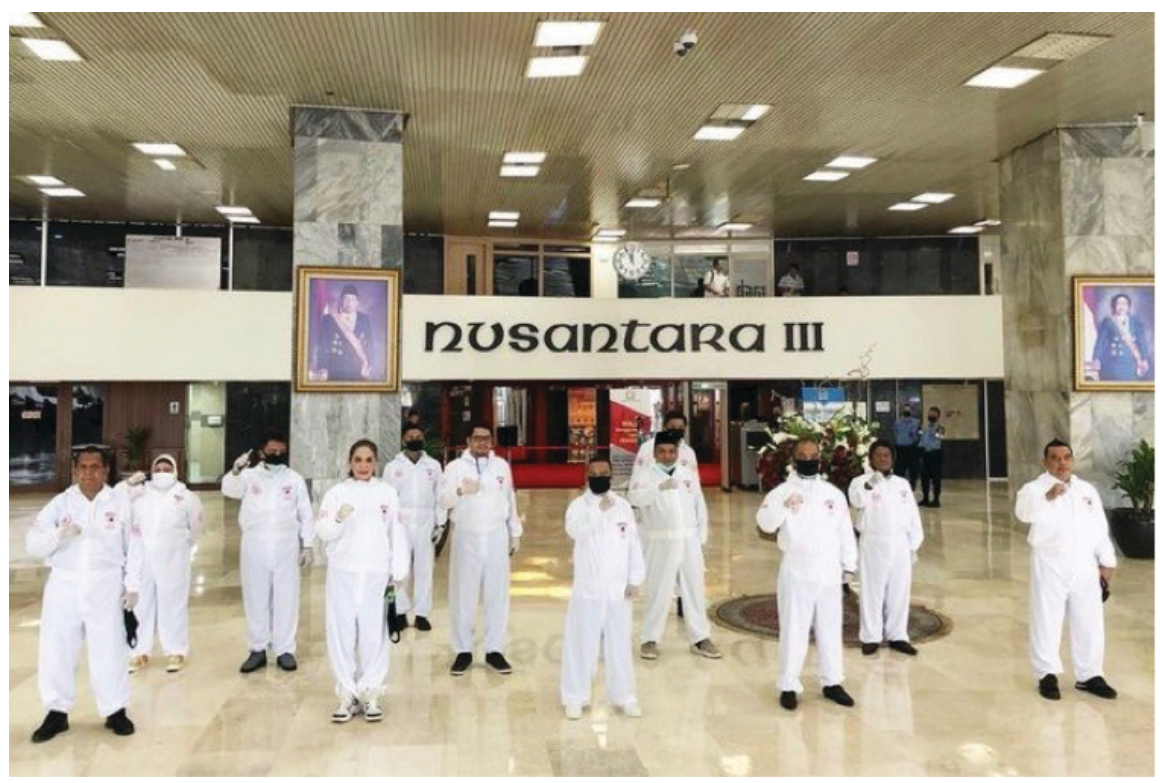

Gambar 2 Tim \#satgaslawancovid19 DPR Sumber: Suwarta (2020)

Dilansir cnn.com internasional, 7 Januari, 2020, ditetapkan bahwa sudah teridentifikasi adanya virus dengan nama coronavirus dan WHO memberi nama 2019-nCoV (CNN Editorial Research, 2020). Lalu dilansir kompas.com, Presiden Jokowi mengumumkan ditemukannya pasien pertama Covid-19 di Indonesia pada hari Senin, 2 Maret 2020 (Ihsanudin, 2020). Jarak 
antara pengumuman pasien pertama Covid-19 dan pengumuman foto seremoni penyerahan buah tangan presiden ke pasien 1, 2 dan 3 Covid-19 hampir satu bulan, tetapi belum menyiratkan keseriusan dalam penanganan, baik menggunakan masker dan jaga jarak.

Gambar 2 adalah foto Tim \#satgaslawancovid19 DPR RI 14 April yang diunggah oleh angota Fraksi Gerindra Habiburohman melalui akuntwitter@habiburokhman. Setelah banyak netizen mempersoalkan foto tersebut, salah satunya seorang dokter dari Fakultas Kedokteran Universitas Indonesia, Berliansah Idris berpendapat bahwa hal tersebut tidak patut dilakukan karena dokter yang di garda terdepan lebih membutuhkan. Dengan ramainya perbincangan di laman sosial media mediaindonesia.com, pada 16 April merilis berita terkait Tim \#satgaslawancovid19 DPR RI menggunakan APD dan tidak mengindahkan protokol Covid-19. Bukan hanya netizen, Politisi Partai Demokrat, Ferdinand Hutahaean menyayangkan perilaku teman sekantornya tersebut. Berlebihan, karena menggunakan perangkat APD yang tidak semestinya digunakan oleh sipil.

Keesokan harinya di istana negara, Presiden melangsungkan pelantikan Wakil Gubenur DKI Jakarta priode 2020 pada 15 April, yang menggunakan protokol pencegahan Covid-19. Terjadi kontradiktif dimana Anggota DPR RI dalam sebuah sesi pemotretan tidak menggunakan protokol Covid-19 dan pelantikan Wagub yang menggunakan protokol Covid-19. Secara denotasi anggota DPR, APD dan masker.

Dilihat secara konotatif, foto tersebut menyiratkan bagaimana kualitas pengetahuan anggota DPR terkait Covid-19, dimana mereka yang ada dalam foto tersebut adalah anggota satgas Covid-19 dari DPR RI. Seharusnya mereka paham mengenai protokol Covid-19. Bisa dilihat bahwa terjadi tidak sinkronnya antara DPR RI dengan protokol kepresidenan. Melihat hal ini pemerintah masih lemah, minimal mampu mendisiplinkan aparat pemerintahnya. Justito menulis di laman remotivi.or.id menilai komunikasi verbal pemerintah memperburuk keadaan, dengan mencontohkan komentar Menteri Kesehatan Terawan Agus Putranto "tak usah terlalu takut corona. Santai saja. Enjoy saja. Yang penting jaga kebugaran dan pola hidup sehat" (Adiprasetio, 2020).

Apabila dilihat lebih dalam lagi dari apa yang foto tersebut tampilkan, memperlihatkan bahwa hubungan antara DPR, APD dan masker, adalah adanya sistem mitigasi bencana yang tidak terstruktur dengan baik. Baik mitigasi bencana alam atau wabah virus yang melanda dunia. Mitigasi dilakukan untuk mengurangi resiko korban. Dilansir liputan6.com, Deputi Bidang Pencegahan dan Kesigapan Badan Nasional Penanggulangan Bencana (BNPB), Bernadus Wisnu Widjadja menyebutkan bahwa mitigasi bencana yang dimiliki Indonesia masih di bawah standar. Apalagi kalau dibandingkan dengan negara lain, baik secara koordinasi, komunitas dan pengetahuan mengenai mitigasi itu sendiri (Makdori, 2019).

Dapat dibayangkan apabila pengetahuan dan koordinasi mitigasi bencana cukup baik, maka foto angota DPR RI beramai-ramai dengan menggunakan APD tidak terjadi. Sayangnya, faktanya ini terjadi, maka hal ini menunjukkan benang merah yang dirilis mengenai mitigasi di 28 Februari 2019, dan mitigasi Covid-19 kali ini ada korelasinya. Dengan perilaku anggota DPR RI yang hendak berangkat mengirimkan bantuan sumbangan ke Rumah Sakit Wisma Atlet Kemayoran Jakarta.

Dua foto di atas menyiratkan adanya kontradiksi antara protokol Presiden dan DPR RI. Secara ideologis, standar protokol Covid-19 adalah kunci dari semua pelaksanaan pemerintahan dan aktivitas masyarakat. Maka dibutuhkan mitigasi bencana yang lebih terpola dan terstruktur agar tidak terjadi simpang siur informasi.

Relasi data yang dilansir oleh dengan komunikasi politik dari pemerintah, dalam hal ini yang menggunakan pendekatan visual masih sangat kurang. Iklan-iklan seremonial dari beberapa 
130 | Kajian Jurnalisme

Volume 04 Nomor 02 Tahun 2021

DOI: $10.24198 / \mathrm{jkj} . \mathrm{v} 4 \mathrm{i} 2.27811$

kementerian, bagi penulis hal tersebut tidak banyak membantu. Dengan tren penggunaan instagram yeng sedang digandrungi, instagram membuat kampanye terkait pandemi Covid-19, seperti hastag \#stayhome, \#foodorder, \#supportsmallbusines pada instagram story atau populer dengan istilah insta story. Pada Agustus 2016, instagram mengeluarkan fitur terbaru untuk mengunggah foto dan video dengan durasi lima belas detik yaitu instagram story (Insani, Hidayat \& Zulfan, 2019). Hal tersebut di manfaatkan sangat baik oleh komika dengan nama panggung Bintang Emon. Seperti yang dilansir kompas.com melalui story instagram Bintang Emon dengan seri Dewan Perwakilan Omel-omel (DPO) "viral" di dunia maya, dengan konten menghimbau social distancing (Riandi, 2020). Kampanye tersebut banyak mendapatkan perhatian khalayak, tampaknya model kampanye seperti itu lebih efektif ketimbang himbauan seremonial kaku ala para pejabat.

Posisi pengetahuan mengenai mitigasi menjadi penting dimiliki oleh pemerintah dan terkomunikasikan minimal kepada semua elemen pemegang keputusan. Tujuannya agar menjadi contoh bagi khalayak. Satu suara dan satu sikap dari berbagai elemen, sebagai contoh pada 6 Mei 2020 Jawa Barat melakukan Pembatasan Sosial Berskala Besar (PSBB), saat masa PSBB di beberapa bagian wilayah Jawa Barat melarang pengoperasian angkutan umum luar kota dan juga pelarangan mudik. Di lain pihak, Menteri Kementrian Perhubungan Republik Indonesia yang diwakili oleh Budi Karya Sumadi menyatakan membuka transportasi antarkota. Hal-hal seperti ini yang membuat ketimpangan informasi di masyarakat.

Seperti yang sudah dijelaskan mengenai apa itu "panopticon", panopticon bekerja dalam satu cara untuk mendapatkan modus kekuatan pikiran di atas pikiran. Efek utamanya adalah kesadaran bahwa saat ini ada yang mengawasi, dilihat, secara terus menerus (Eldija, F.D. \& Mastutie, 2016), dengan catatan, koordinasi antara lembaga terkoordinasi dengan baik. Maka dengan adanya identitas baru, dalam kaitanya dengan new normal, yakni menyatukan perbedaan adalah sebagai cara dalam penguatan sumber daya manusia dan sekaligus modal dalam pembangun (Albar, 2017). Penguatan sumber daya manusia (SDM) menjadi utama, karena apabila SDM tidak "sehat", semua hal dalam urusan kenegaraan akan terhambat. Maka baru mulai berfikir untuk bersama melawan pandemi Covid-19.

Dari paparan dua foto di atas, tidak menafikan ada hal yang bisa diambil. Tetapi tulisan ini lebih mencoba menawarkan cara membaca baru, hal ini dalam visual, karena dimasa pandemi ini seakan semua ada di layar. Cara membaca visual dalam layar monitor ini yang penulis coba bongkar. Dalam hal ini melalui bahasa visual bisa menjadi salah satu cara bersiasat mengatasi persoalan yang cukup pilu.

Hal ini karena bukan hanya soal wabah pandemi, melainkan ada hal lain yang perlu ditelaah. Pandemi hadir di era informasi, salah satu poin dalam informasi adalah budaya visual. Hampir semua media menyadari bahwa visual adalah salah satu senjata yang bisa mengiring khalayak membaca media tersebut. Visual bisa memberikan informasi lebih cepat dipahami, tetapi bisa jadi terjerumus pada hoax. Hal ini bisa dilihat di masa pemilihan presiden 2019. Hoax disebarluaskan cukup efektif menggunakan visual. Wibowo memaparkan penemuan terkait hal tersebut, bahwa hoax disebar menggunakan tampilan "seakan-akan" potongan gambar yang di screnshoot dari media online tersebut. Hal ini cukup efektif, karena pembacaan dalam visual atau literasi visual masih sangat minim untuk pendidikan di Indonesia.

Literasi visual di masa orde baru masih terkait dengan gambar dua gunung dan matahari diataranya, tidak lupa dilengkapi dengan hamparan sawah, rumah sederhana dan sebagainya. Penanda dan petanda yang ingin dibangun adalah ilusi dari bentuk lukisan "mooi Indie". Maka dengan ini, seperti apa yang kita rasakan dan Foucault (1976) sudah menuliskan situasi pandemi Covid-19 dengan istilah biopower. Hal ini bisa diasumsikan sebagai sesuatu yang 
membekas, seyogianya kita perlu belajar dari sejarah peradaban umat manusia setiap generasi, maka jangan sampai terulang hal serupa. Wabah datang dan kita belum siap.

Tabel 1. Ringkasan Hasil Penelitian

\begin{tabular}{|c|c|c|c|}
\hline Foto & Denotasi & Konotasi & Mitos \\
\hline $\begin{array}{l}\text { Pelantikan Wakil } \\
\text { Gubenur Jakarta } \\
\text { priode } 2020 \\
\text { (gambar 1) }\end{array}$ & $\begin{array}{l}\text { - Salam Hormat } \\
\text { - Pelantikan Wakil } \\
\text { Gubenur } \\
\text { - Masker } \\
\text { - Jaga Jarak }\end{array}$ & $\begin{array}{l}\text { - Berbahaya } \\
\text { - Tidak Biasa }\end{array}$ & $\begin{array}{l}\text { Pada bagain mitos, } \\
\text { sebagai salah satu } \\
\text { cara menaturalisasi } \\
\text { denotasi dan konotasi. } \\
\text { Penulis melihat konteks } \\
\text { "Budaya Seremoni" } \\
\text { menjadi salah satu } \\
\text { alasan terbesar } \\
\text { pelantikan ini di } \\
\text { dilakukan secara tatap } \\
\text { muka. }\end{array}$ \\
\hline $\begin{array}{l}\text { Tim } \\
\text { \#satgaslawancovid19 } \\
\text { DPR RI } \\
\text { (gambar 2) }\end{array}$ & $\begin{array}{l}\text { - Dewan Perwakilan } \\
\text { Rakyat } \\
\text { - Alat Pelindung } \\
\text { Diri (Tim } \\
\text { \#satgaslawancovid19 } \\
\text { DPR RI) } \\
\text { - Foto Besama } \\
\text { - Masker }\end{array}$ & $\begin{array}{l}\text { - Komunikasi } \\
\text { - Mitigasi } \\
\text { - Bencana } \\
\text { - Pandemi }\end{array}$ & $\begin{array}{l}\text { Penulis melihat, mitos } \\
\text { dari foto ini adalah } \\
\text { kurangnya "Sosialisasi } \\
\text { dan Komunikasi } \\
\text { Politik" dua konteks } \\
\text { ini yang menjadi } \\
\text { persoalan dalam foto } \\
\text { \#satgaslawancovid19 }\end{array}$ \\
\hline
\end{tabular}

Sumber: Peneliti 2020

\section{SIMPULAN}

Pengetahuan mengenai media baru dan kemampuan mengenai mitigasi bencana adalah kunci dalam menangani pandemi Covid-19, selanjutnya ditambah dengan penguasan komunikasi politik dari pemerintah. Maka merujuk pada dua foto yang dianalisis, secara ideologi tergambar dalam kepemimpinan Presiden Joko Widodo tidak mampu mengkoordinasikan semua elemen yang terkait dengan pandemi Covid-19, Dalam penanganan Covid-19 harus ada koordinasi antara hubungan ilmu pengetahuan, pada konteks ini adalah komunikasi visual dengan ilmu politik, dua hal tersebut harus beriringan untuk menghasilkan sebuah tatanan baru pada khalayak. Hal ini dilihat dari kontradiktif antara denotasi dan konotasi dari setiap foto, bagaimana proses pelantikan yang sesuai protokol lalu di lain waktu anggota Dewan Perwakilan Rakyat dilihat dari fotonya tidak memahami konteks pandemi.

Medium fotografi bisa menjadi sebuah pilihan dalam mengkonstruksi atau pun bisa juga mengaburkan cara pandang khalayak, seperti yang terjadi dalam dua foto yang penulis analisis. Jawaban mengenai bagaimana kekuatan visual mampu mendisiplinkan khalayak adalah dalam dua foto ini terjadi kontraproduktifkarena saling berlawanan secara makna. Hal ini diakibatkan karena lemahnya pengetahuan dan koordinasi dalam mengorkestrasi lembaga terkait untuk menyelesaikan mitigasi dan protokol pandemi Covid-19. 
132 | Kajian Jurnalisme

Volume 04 Nomor 02 Tahun 2021

DOI: $10.24198 / \mathrm{jkj} . \mathrm{v} 4 \mathrm{i} 2.27811$

\section{DAFTAR PUSTAKA}

Abel, H. (2020, April 9). On the Ethics of Documenting a Pandemic. Diakses dari https://www. bjp-online.com/2020/04/on-the-ethics-of-documenting-a-pandemic/.

Adiprasetio, J. (2020, March 23). Covid-19: Saat Ini Kita Membutuhkan Paranoia, Lebih dari Kapanpun. Diakses dari https://remotivi.or.id/amatan/578/covid-19-saat-ini-kitamembutuhkan-paranoia-lebih-dari-kapanpun

Albar, M. W. (2017). Representasi Budaya Visual Karya Seni Rupa Kontemporer Putu Sutawijaya, 1998-2010. Lensa Budaya, 12(2). https://doi.org/10.34050/jlb.v12i2.3053

Barger, J. (2008). Ways of Seeing. London: Penguin Classic.

Barthes, R. (2010). Camera Lucida: Reflections on Photography. New York: Hill and Wang.

Barthes, R. (2010). Image-Music-Text. New York: Hill and Wang.

Bazin, A., \& Gray, H. (2009). What Is Cinema? Vol. 1. London: University of California Press.

Benjamin, W. (1972). A short history of photography. Screen, 13(1). https://doi.org/10.1093/ screen/13.1.5

Benjamin, W. (2008). The Work of Art in the Age of Mechanical Reproduction. London: Penguin.

Burhan, F. A. (2020, March 27). Pengguna WhatsApp dan Instagram Melonjak 40\% Selama Pandemi Covid-19. Dikses dari https://katadata.co.id/berita/2020/03/27/penggunaanwhatsapp-dan-instagram-melonjak-40-selama-pandemi-corona.

CNN Editorial Research. (2020, January 7). Corona Outbreak Timeline Fast Facts. Diakses dari https://edition.cnn.com/2020/02/06/health/wuhan-coronavirus-timeline-fast-facts/ index.html

Colberg, J. (2013, September 16). A Conversation with Thomas Weski. Diakses dari https:// cphmag.com/conv-thomas-weski/.

Demos, T. J. (2006). Vitamin Ph: New Perspectives in Photography. New York: Phaidon Press.

Eldija, F.D; Mastutie, F. (2016). Panoptic Archtecture. Media Matrasain, 13(1), 16-23.

Fathurrohman. (2020, April 15). Pelantikan Wagub DKI. Diakses dari https://fin. co.id/2020/04/15/pelantikan-wagub-dki/.

Fidler, R. (2010). Mediamorfosis: Memahami Media Baru. Yogyakarta: Bentang Budaya.

Fiske, J. (2004). Cultural and Communication Studies: Sebuah Pengantar Paling Komprehensif. Yogyakarta: Jalasutra.

Foucault, M. (1970). Discipline and Punish. New York: Vintage Books, A Division of Random House.

Foucault, M. (1976). The History of Sexuality. Paris: Gallimard.

Foucault, M. (2014). Abnormal: In his Lectures at the College'ge de France 1974-1975. London: Picador.

Haq, A. D., Fadilah, E. (2018). Transformasi Harian Kompas Menjadi Portal Berita Digital Subscription Kompas.id. Jurnal Kajian Jurnalisme, 1(2). https://doi.org/10.24198/jkj. v1i2.21339

Hariyanto. (2017). Jejak karakter bangsa dalam Budaya Visual Indonesia. Jurnal Universitas Malang, 3(3).

Hemingway, A. F. (2006). Marxism and the History of Art: From William Morris to the New Left. London: Pluto Press.

Ihsanudin. (2020, March 3). Fakta Lengkap Pertama Virus Corona di Indonesia. Diakses dari https://nasional.kompas.com/read/2020/03/03/06314981/fakta-lengkap-kasus-pertamavirus-corona-di-indonesia?page $=$ all.

Insani, N.C., Hidayat, D.R., Zulfan, I. (2019). Pemanfatan Insta Story Dalam Aktivitas Jurnalistik Oleh Majalah Gadis. Jurnal Kajian Jurnalisme, 3(1). https://doi.org/10.24198/ 
DOI: $10.24198 / j k j . v 4 i 2.27811$

jkj.v3i1.22453

Jufri, K. (2010, November 8). Wrath of the Fire Mountain. Diakses dari https://www. worldpressphoto.org/collection/photo/2011/30197/12/2011-Kemal-Jufri-PNS2-AL.

Kangsong, U. (2020, April 1). Panopticon Covid-19. Diakses dari https://mediaindonesia.com/ podiums/detail_podiums/1791-panopticon-covid-19.

Makdori, Y. (2019, February 28). BNPB: Mitigasi Bencana Masyarakat Indonesia Masih di Bawah Standar. Diakses dari https://www.liputan6.com/news/read/3906325/bnpbmitigasi-bencana-masyarakat-indonesia-masih-di-bawah-standar\#.

Mandoki, K. (2012). Everyday aesthetics: Prosaics, the play of culture and social identities. London: Ashgate Publishing.

Rayner, P., Peter, W., \& Stephen, K. (2001). Media Studies: The Essential Introduction. New York: Routledge.

Riandi, A. P. (2020, May 8). Deretan DPO Bintang Emon yang Viral di Dunia Maya. Diakses dari https://www.kompas.com/hype/read/2020/05/08/110014266/deretan-video-dpobintang-emon-yang-viral-di-dunia-maya?page $=$ all.

Slater, P., \& Althusser, L. (1980). For Marx. Contemporary Sociology, 9(1). https://doi. org/10.2307/2065654

Smith, S. M. (2013). At the Edge of Sight: Photography and the Unseen. Durham: Duke University.

Sunardi, S. T. (2004). Semiotika Negativa. Yogyakarta: Penerbit Buku Baik.

Suwarta. T. H. (2020, April 16). Anggota DPR Foto pakai APD, Tenaga Medis: Maki Sulit Dapat. Diakses dari https://mediaindonesia.com/read/detail/304700-anggota-dpr-fotopakai-apd-tenaga-medis-kami-sulit-dapat.

Tim Komunikasi Publik Gugus Tugas Nasional. (2020, May 11). Infografis COVID-19 (11 Mei 2020). Diakses dari https://covid19.go.id/.

Trifonas, P. (2003). Seri Posmodern: Barthes dan Imperium Tanda. Yogyakarta: Penerbit Jendela.

Voloshinov, V. (1986). Marxism and the Philosophy of Language. Cambridge: Harvard University Press.

Wolff, J. (2015). After Cultural Theory: The Power of Images, the Lure of Immediacy. Sage Publication. 